\title{
POLAASUH OTORITER-DEMOKRATIS DALAM MENANAMKAN PENDIDIKAN ANTI KORUPSI
}

\author{
Ilham Andika Putra, Cecep Darmawan, Syaifullah Syam \\ Universitas Pendidikan Indonesia \\ Email: ilhamandikaputra@student.upi.edu
}

\begin{abstract}
Abstrak
Penelitian ini dilatarbelakangi oleh pentingnya meningkatkan kesadaran anti korupsi. pendidikan anti korupsi ini harus dimulai dari keluarga sebagai tempat pendidikan pertama bagi anak. Khususnya dalam penelitian ini akan mengkaji bagaimana pentingnya pola asuh orang tua sebagai agen pendidikan pertama dalam menanamkan pendidikan anti korupsi. dari ketiga pola asuh antara otoriter, demokratis dan permisif, pola asuh yang akan dikaji hanya pola asuh otoriter-demokratis. Hal ini sesuai dari topik dalam kajian ini yang terfokus pada pola asuh otoriter-demokratis yang diterapkan orang tua dalam mengatasi timbulnya sikap korupsi. informan yang digunakan dalam penelitian ini sebanyak 5 keluarga inti yang mempunyai anak di Kota Bandung. Orang tua dengan kriteria berusia pendidikan terakhir SD sampai perguruan tinggi dan sedangkan anak berusia pendidikan SD sampai SMP. Penelitian ini bertujuan untuk meningkatkan kesadaran dan pengetahuan orang tua tentang pentingnya pendidikan anti korupsi dan pemilihan pola asuh yang tepat dalam mendidik anak agar tujuan dari pendidikan anti korupsi tercapai dengan baik.
\end{abstract}

Kata kunci: $\quad$ Korupsi, Pendidikan anti korupsi, Pola asuh orang tua

\section{PENDAHULUAN}

korupsi adalah penyakit yang ada pada diri manusia baik disadari maupun tidak disadari yang sifatnya melawan hukum dan perbuatannya adalah seperti perbuatan memperkaya diri sendiri atau orang lain atau suatu korporasi yang dapat merugikan baik secara kecil dan besar. Korupsi menurut Dewi (2014) bahwa korupsi adalah: "suatu perbuatan tidak jujur dengan maksud untuk memperkaya diri sendiri dan atau orang lain dengan cara menyelewengkan ataupun menggelapkan keuangan negara".

Indonesia adalah salah satu negara yang aktif memberantas korupsi di-Dunia khususnya ASEAN, sudah banyak kasuskasus korupsi telah terpecahkan hal ini membuktikan Indonesia mampu menjadi negara yang cukup baik dalam menegakkan hukum untuk korupsi. Hal ini menjadi prestasi bagi Indonesia selama beberapa dekade silam sejak zaman Orde baru sampai sekarang. seperti yang tercantum pada laman (transparency International the global coalition against corruption, 2016) "corruption perception index in Indonesia 2016, berada pada rangking ke 90 dari 176 negara di dunia, dan sedangkan skor indeks korupsi Indonesia berada pada skor 37/100"

Kemudian data ini diperkuat dalam Paparan Ketua KPK Priode 2011-2015 Abraham Samad di Universitas Pendidikan Indonesia pada tanggal 13 februari 2018 menyatakan bahwa:

Pada tahun 2011, CPI Indonesia 3,0 (rangking 100 dari 183 negara), selanjutnya pada tahun 2012, CPI

Indonesia naik 3,2 (Namun Turun peringkat menjadi 118 dari 182) negara Indonesia masih kalah dengan Timor Leste (3,3), kemudian pada tahun 2013 CPI Indonesia tetap 3,2 (Tetapi Peringkatnya naik ke

104 dari 177 negara), sedangkan pada tahun 2014, CPI Indonesia naik menjadi 3,4 (Peringkat 107 dari 177 negara), di tahun selanjutnya 2015, CPI Indonesia naik menjadi 3,6 (peringkat membaik menjadi urutan 88 secara global dan urutan 15 skala 
regional), dan pada tahun 2016, CPI Indonesia naik satu poin sebesar 37 dari angka tertinggi 100 , tetapi secara global posisi Indonesia masih berada di urutan ke90 dari 176 negara.

Walaupun indeks persepsi korupsi Indonesia meningkat, Indonesia masih terus bekerja keras dalam memberantas korupsi untuk menjadi negara yang bersih dari korupsi. Pengenalan tentang anti korupsi harus di mulai sejak dini di keluarga. karena banyak kasus korupsi Indonesia ini beraneka ragam mulai dari sektor swasta, pemerintahan kecil seperti RT dan RW sampai ke elit-elit politik.

Keluarga adalah satu-satunya lembaga sosial dasar sebagai titik awal dari semua perkembangan dan diberikan tanggung jawab untuk mengubah suatu organisme biologis menjadi manusia yang dapat beradaptasi dengan lingkungan sekitar, terdiri dari anggotanya yaitu ayah, ibu dan anak yang diikat berdasarkan asas saling menghormati, menghargai, dan mendukung peran masingmasing sehingga tercipta sinegri dan keteraturan. Keluarga menurut Prasanti (2016) adalah sebuah sistem yang terdapat hubungan komunikasi yang harmonis dan mengutamakan dimensi Fisik yang konkret agar terjalin hubungan yang kuat.

Keluarga sebagai agen sosialisasi dan pendidikan pertama bagi anak, harus menjadi tempat ditanamkannya pendidikan anti korupsi, karena anak lahir dan dibesarkan serta ditanamkan nilai-nilai kebaikan yang dimiliki oleh orang tuanya. Sebelum menanamkan pendidikan anti korupsi orang tua juga harus mengetahui apa itu korupsi secara mendalam. Setelah memiliki nilai yang baik tentang anti korupsi orang tua harus tahu pola asuh mana yang tepat untuk mendidik anaknya sekaligus menanamkan pendidikan anti korupsi agar penanaman nilai tertanam dengan baik. Menurut Asrar (2012) pola asuh merupakan perilaku yang dipraktikkan oleh pengasuh (ibu, bapak, nenek, atau orang lain) dalam pemberian makan, pemeliharaan kesehatan, pemberian stimulasi, serta dukungan emosional yang dibutuhkan anak untuk tumbuh kembang.

Pola asuh merupakan perilaku orang tua atau yang mengasuh dalam rangka merawat, memelihara, membimbing, melatih, memberikan pengaruh, dan mendukung emosional dengan harapan termbentuk tingkah laku sesuai dengan lingkungan diama dia tinggal. Untuk itu pengetahuan orang tua tentang pola asuh pun harus mempuni agar bisa memilih pola asuh yang tepat dalam mendidik anaknya sebelum orang tua menerapkan pola asuh tersebut.
Pola asuh yang dianjurkan untuk menanamkan pendidikan anti korupsi ini adalah otoriterdemokratis. Hal ini sesuai dengan penelitian dari Riris Dwi Setianing (2015) bahwa adanya penyeimbangan pola asuh otoriter dan demokratis yang dinilai sangat cocok untuk perkembangan anak. Maka dari itu peneliti memilih pola asuh otoriter-demokratis sebagai pola asuh yang baik untuk menanamkan pendidikan anti korupsi.

\section{TINJAUAN PUSTAKA \\ 2.1. Konsep Pola Otoriter-Demokratis}

Kearifan lokal atau local wisdom dikenal juga Dalam kehidupan keluarga terdapat penanaman nilai dari orang tua ke anak. proses ini dilakukan dengan pola asuh yang diterapkan orang tua sebagai media penanamannya agar proses penanaman nilai tersampaikan dengan baik.

Pola asuh dalam Apriastuti (2013, hlm. 2) adalah bentuk-bentuk yang diterapkan dalam rangka merawat, memelihara, membimbing, melatih, dan memberikan pengaruh. Selain itu, pola asuh dalam Asrar (2012, hlm. 3) merupakan perilaku yang dipraktikkan oleh pengasuh (ibu, bapak, nenek, atau orang lain) dalam pemberian makan, pemeliharaan kesehatan, pemberian stimulasi, serta dukungan emosional yang dibutuhkan anak untuk tumbuh kembang. Dan kemudian menurut Widyawati (2006, hlm. 5) Pada dasarnya pola asuh adalah tujuan untuk mengajarkan, membentuk tingkahlaku pada anak yang disesuaikan dengan aturan-aturan yang telah diberlakukan pada kelompok budaya tempat ia dibesarkan.

Dari beberapa pengertian pola asuh di atas dapat ditarik kesimpulan bahwa Pola asuh merupakan perilaku orang tua atau yang mengasuh dalam rangka merawat, memelihara, membimbing, melatih, memberikan pengaruh, dan mendukung emosional dengan harapan termbentuk tingkah laku sesuai dengan lingkungan dimana dia tinggal.

\subsection{Pola Asuh Otoriter}

Pola asuh otoriter adalah salah satu dari 3 pola asuh yang diterapkan dalam keluarga untuk menanamkan nilai serta karakter. Untuk itu pola asuh sangat penting dalam mendidik anak dan dalam penelitian ini akan berfokus pada pola asuh otoriter-demokratis saja.

Pola asuh otoriter menurut Timpanometri (2012, hlm. 4) bahwa pola asuh Otoriter (authoritarian parenting), Pola asuh otoriter adalah pola asuh dimana anak mengikuti pendapat dan keinginan orang tua. Orang tua cenderung 
memaksakan kehendak, terus mengatur tanpa memperhatikan kemauan sang anak. Kemudian pola asuh otoriter menurut Apriastuti (2013, hlm. 7) bahwa pola asuh otoriter adalah pola asuh yang bersifat lebih memaksa anak untuk mengikuti keinginan orang tua. Dan pola asuh otoriter menurut Widyawati (2006, hlm. 8) pola asuh otoriter adalah pola yang menetapkan peraturanperaturan dan batasan-batasan yang bersifat mutlak serta memberitahukan kepada anak bahwa mereka harus mematuhi peraturan tersebut.

Dari pemaparan diatas dapat disimpulkan bahwa pola asuh otoriter adalah pola asuh yang yang cara penanaman dan pengasuhan bersifat mutlak mulai dari peraturan dan batasan dan berpusat ke orang tua sebagai pemegang kendali.

\subsection{Polas Asuh Demokratis}

Pola asuh demokratis adalah salah satu dari 3 pola asuh yang diterapkan pada keluarga dalam mendidik anaknya.

Pola asuh demokratis menurut Timpanometri (2012, hlm. 4) adalah merupakan suau pola asuh yang lebih menekankan anak terhadap aspek pendidikan dibanding aspek hukuman. Kemudian pola asuh demokratis menurut Apriastuti (2013, hlm. 7) bahwa pola asuh demokratis adalah pola yang bersifat memperlihatkan kebutuhan anak. Selanjutnya pola asuh menurut Widyawati (2006, hlm. 8) adalah pola yang penerapannya dengan membuat peraturan-peraturan yang jelas dan juga menjelaskan harapan mereka pada anak mereka, semua itu dijelaskan melalui diskusi.

Dari pemaparan di atas dapat disimpulkan bahwa pola asuh Demokratis, adalah pola dengan menggunakan sistem kesepakatan dan mementingkan kebutuhan.

\subsection{Konsep Pendidikan Anti Korupsi}

Pendidikan anti korupsi dalam Hakim (2014, hlm. 145) pengertian dari pendidikan anti korupsi adalah proses pembentukan pengetahuan dan pemahaman mengenai bentuk korupsi dan aspekaspeknya, pengubahan persepsi dan sikap terhadap korupsi, dan proses pembentukan keterampilan dan kecakapan melawan korupsi

Selanjutnya dalam Indawati (2015, hlm. 84) menyatakan bahwa pendidikan anti korupsi adalah usaha sadar dan terencana untuk mewujudkan proses belajar mengajar yang kritis terhadap nilai-nilai anti korupsi. Dalam proses tersebut pendidikan anti korupsi bukan sekedar media bagi transfer pengetahuan, namun juga menekankan pada upaya pembentukan karakter, nilai anti korupsi, dan kesadaran moral dalam melakukan perlawanan terhadap perilaku korupsi.
Selain itu ada juga pengertian pendidikan anti korupsi dalam Yaqin $(2015$, hlm. 4) pendidikan anti korupsi adalah proses pengenalan, pemahaman nilai, penghayatan nilai anti korupsi menjadi kebiasaan hidup sehari-hari.

Pendidikan anti korupsi dalam Rusdini (2016, hlm. 25) adalah sebagai usaha sadar untuk memberikan pemahaman tentang bahaya korupsi dan mencegah terjadinya perbuatan korupsi yang dilakukan selama proses pembelajaran di sekolah. Pendidikan antikorupsi pada dasarnya dapat dilakukan pada pendidikan informal di lingkungan keluarga, pendidikan non formal di lingkungan masyarakat serta pendidikan formal pada lingkungan sekolah.

Dari pemaparan di atas dapat disimpulkan bahwa pendidikan anti korupsi dimaknai dengan upaya secara sadar dan terencana dari segi afektif, kognitif, dan psikomotorik yang digunakan untuk memberantas korupsi melalui pendidikan baik pendidikan secara formal maupun informal.

\section{METODE}

Penelitian ini menggunakan pendekatan kualitatif dengan menggunakan metode deskriptif analisis. Penelitian ini dilakukan di Panorama Kelurahan Hegarmanah, Kecamatan Cidadap, Kota Bandung, Jawa Barat. Alasan peneliti memilih Panorama Kelurahan Hegarmanah, Kecamatan Cidadap, Kota Bandung sebagai lokasi penelitian karena lokasi penelitian yang padat penduduk, banyak anak-anak yang berada di usia pendidikan SD sampai SMP, dan akses yang memudahkan peneliti untuk melakukan penelitian secara intensif dan mendalam.

Sedangkan subjek yang akan di ambil dalam penelitian ini yaitu keluarga inti atau orang tua suami dan istri yang memiliki anak. orang tua disini memiliki kriteria berpendidikan rendah sampai perguruan tinggi, sedangkan kriteria anak yang berusia pendidikan SD-SMP. Pemilihan partisipan untukpenelitian ini menggunakan purposive sampling dan snowball sampling. Kemudian hasil penelitian ini diperoleh melalui teknik observasi, wawancara, studi dokumentasi, dan studi pustaka.

\section{HASIL DAN PEMBAHASAN}

Dari temuan penelitian Otoriter-demokratis menjadi pola asuh yang ideal untuk menanamkan pendidikan anti korupsi. Untuk itu pola asuh demokratis dan otoriter tidak bisa berdiri sendiri dalam menanamkan pendidikan karakter pendidikan anti korupsi, penemuan ini diperkuat dari penelitian Riris Setianing (2015) bahwa "pola 
asuh otoriter dan demokratis yang dipadukan dinilai sangat cocok untuk perkembangan anak".

Jika kelurga hanya menggunakan pola asuh otoriter, dikhwatirkan anak akan membangkang dan ada ketimpangan sikap anak, yaitu ketimpangan antara sikap anak di rumah dan diluar rumah. Anak yang didik menggunakan pola asuh otoriter cenderung berperilaku seenaknya di luar rumah karena merasa bebas dari aturan yang mutlak dari orang tua.

Ketika orang tua hanya menggunakan pola asuh demokratis saja, ancaman yang dapat merusak proses penanaman pendidikan anti korupsi ini adalah pengaruh yang berasal dari luar atau masyarat. Hal ini terjadi karena anak yang berpola asuh demokratis terbiasa diberi kepercayaan oleh orang tua, sehingga ketika ia jauh dari rumah dimana tidak ada kontrol langsung dari orang tua sehingga akan mudah terpengaruh dengan lingkungan. Anak yang dibesarkan dengan pola asuh demokratis memiliki prinsip yang dibentuk oleh diri sendiri, sehingga perpaduan dari pola asuh otoriter yang aturannya tegas dan demokratis yang membebaskan namun tetap dalam kontrol membuat anak tetap dalam batas wajar dan teguh pendiriannya karena didikan orang tuanya yang baik. Sebaliknya apabila anak tidak di kontrol dengan baik anak bisa saja berperilaku sebaliknya dari apa yang ditanamkan oleh orang tua akibat pengaruh lingkungan khususnya lingkungan teman sebayanya.

Untuk itu harus adanya perpaduan antara dua pola asuh ini agar menjadi pola asuh yang ideal. Pola asuh otoriter-demokratis ini ideal karena karena pola asuh demokratis ini bisa melihat kebutuhan anak dan langkah apa yang akan diambil untuk melaksanak hal tersebut kemudian pada pola asuh anak akan diberikan batasan yang tegas dan harus dipatuhi sehingga anak akan melakukan segala sesuatu sesuai aturan.

Hal ini sesuai dari data temuan dari salah satu informan yang berpola asuh otoriter-demokratis. Anaknya menjadi anak yang teguh pendirian, mandiri, bisa membedakan mana yang baik dan benar, cenderung mendengarkan orang tua dan ramah. Maka dari itu pola asuh otoriter dan demokratis ini ideal dalam mengembangkan kepribadian anak.

Dapat di simpulkan bahwa Pola asuh otoriterdemokratis adalah pola asuh yang paling ideal untuk menanamkan pendidikan anti korupsi dengan menyeimbangkan dan mengkolaborasikan keduanya. Otoriter yang tegas harus sekali-sekali menjadi demokratis agar anak bisa berkembang dengan baik dan demokratis harus sekali-sekali otoriter agar anak berada pada jalur yang benar dengan adanya pengawasan yang baik oleh orang tua. Kemudian bisa diantara suami dan istri menerapkan kedua pola asuh ini baik itu istri atau suami harus memilih salah satu dari pola ini, agar lebih mudah dalam mengintegrasikannya dalam mendidik anak khususnya dalam menanamkan pendidikan anti korupsi. kemudian ditemukan bahwa pola asuh otoriter dan demokratis bisa juga di baur dan menjadi pola asuh yang baru, yaitu pola asuh tersebut bisa menjadi pola asuh otoriter semi demokratis atau demokratis semi otoriter. Sehingga dalam penerapannya fungsi dari keluarga akan berjalan dengan baik, dan tujuan untuk menanamkan pendidikan anti korupsi tercapai.

Akan tetapi dalam proses penanaman pendidikan anti korupsi terlebih dahulu orang tua harus paham apa itu korupsi dan bagaimana cara mengatasinya sehingga dapat di terapkan dalam kehidupan dengan mengunakan media pola asuh otoriter-demokratis ini. Untuk lebih mudah dalam mengetahui apa dan bagaimana pendidikan anti korupsi orang tua harus memperdalam ilmu agama khususnya agama islam, ilmu disini bukan hanya senang Shalat dan membaca Al'quran tetapi juga membumikan agama Allah SWT. Karena pendidikan agama islam dan pendidikan anti korupsi itu selajan, hal ini sesuai dengan penelitian Lukman Hakim (2014) yang menyatakan bahwa "adanya keselarasan pendidikan anti korupsi dan pendidikan agama islam sehingga memudahkan proses pengintegrasian antar keduanya". Maka dari itu pentingnya orang tua memperdalam ilmu keagamaan khususnya islam, karena jika orang tua memiliki akhlak yang baik maka anaknya juga akan mengikuti akhlak orang tuanya, seperti pepatah "buah tidak jatuh jauh dari pohonnya". Jika orang tua sudah memiliki akhlak yang baik maka untuk menerapkan pendidikan anti korupsi ini dengan bantuan media dari pola asuh otoriterdemokratis akan berlangsung lancar.

\section{KESIMPULAN}

Pola asuh otoriter-demokratis dalam menanamkan pendidikan anti korupsi di Kota Bandung sangat penting, dimana keluarga sebagai pendidikan pilar pendidikan pertama dan tempat sosialisasi sekunder dan sebelum anak masuk kelingkungan dan diajarkan dengan pendidikan diluar, pendidikan orang tua harus kuat karena orang tua adalah fondasi awal, pendidikan disini adalah pendidikan tentang penerapan pola asuh yang baik dan juga pengetahuan tentang anti korupsi yang baik. Jika keluarga tidak memiliki pengetahuan yang baik tentang pendidikan anti korupsi maka akan berdampak pada anak yang akan melakukan tindakan yang dapat menyebabkan korupsi nantinya. Pola asuh yang dipilih oleh orang tua juga akan berdampak pada mudah dan sulitnya penanaman pendidika 
karakter anti korupsi. Pola asuh yang terbaik adalah otoriter-demokratis, dikarenakan anak akan terus terawasi dan diarakan dengan nilainilai anti korupsi.

Pola asuh otoriter-demokratis adalah pola asuh yang paling ideal untuk menanamkan pendidikan anti korupsi dengan menyeimbangkan dan mengkolaborasikan keduanya otoriter yang tegas harus sekali-sekali menjadi demokratis agar anak bisa berkembang dengan baik dan demokratis harus sekali-sekali otoriter agar anak berada pada jalur yang benar dengan adanya pengawasan yang baik oleh orang tua. Atau bahkan antara suami dan istri menerapkan kedua pola asuh ini, agar lebih mudah dalam mengintegrasikannya dalam mendidik anak.

\section{REFERENNSI}

Apriastuti, D. A. (2013). Analisis Tingkat Pendidikan dan Pola Asuh Orang Tua Dengan Perkembangan Anak Usia 48-60 Bulan. Jurnal Ilmiah Kebidanan, 4(1), hlm $1-14$.

Asrar, M. (2012). Pola Asuh, pola makan, asupan zat gizi dan hubungannya dengan status gizi anak balita masyarakat Suku Nuaulu di Kecamatan Amahai Kabupaten Maluku Tengah Provinsi Maluku. 6 (2), hlm 1-11

Dewi, K. K. (2014). Efektifitas Penerapan Ancaman Sanksi Pidana Tambahan Guna pengembalian Kerugian Keuangan Negara Dalam Tindak Pidana Korupsi (Studi Kasus Di Pengadilan Negeri Denpasar). Magister Hukum Udayana, 358.

Hakim, L. (2014). Model Integrasi Pendidikan Anti Korupsi dalam Kurikulim Pendidikan Islam. Jurnal Pendidikan Agama Islam, hlm 145.

Indawati, N. (2015). Pengembangan Mata Kuliah Pendidikan Anti Korupsi untuk Mengefektifkan Nilia-Nilai pada Mahasiswa Pendidikan Guru Sekolah Dasar di Universitas Kanjuruhan Malang. Prosiding Seminar Nasional dan Call For Papers Pendidikan Karakter dalam Pembelajaran Bisnis dan Manajemen, 84.

Prasanti, D. (2016). Perubahan Media Komunikasi dalam Pola Komunikasi Keluarga di Era Digital. Jurnal Komunikasi dan Media, hlm 12.

Samad, Abraham. (2018, Februari 13). Korupsi di Indonesia. Universitas Pendidikan Indonesia, Bandung, Jawa Barat, Indonesia.

Setianning, Riris Dwi. (2015). Pola Asuh Anak pada Keluarga Militer. Jurnal Mahasiswa Sosiologi, hlm 1-26
Siti Ekowati Rusdini, M. R. (2016). Pelaksanaan Internalisasi Kejujuran dalam Pendidikan Anti Korupsi di SMP Keluarga Kudus. Journal of Educational Social Studies, hlm 25.

Timpanometri, D. (2012). Gambaran Pola Asuh Ibu Suku Batak Pada Anak Laki-Laki dengan Gangguan Autisme. Jurnal Penelitian, hlm 4-5.

transparency International the global coalition against corruption. (2016, desember 11). corruption perception index 2016. Dipetik februari

13 , 2018,transparency.org:https://www.transpar ency.org/news/feature/corruption_perception s_index_2016

Widyawati, K. E. (2006). Hubungan Antara Tingkat Persepsi Pola Asuh Otoriter Orang Tua dengan kepercayaan Diri pada Remaja Kelas XI Siswa SMUN 2 Surabaya. Surabaya: Fakultas Psikologi Universitas Airlangga.

Yaqin, N. (2015). Program Pendidikan Anti Korupsi di Madrasah. Jurnal Studi Islam, hlm 4. 